\title{
THE JOURNAL OF INTERDISCIPLINARY HISTORY
}

Robert I. Rotberg and Theodore K. Rabb, Editors

"JIH publishes many of the most exciting statefully edited, the articles - Richard L. McCormick, of-the-art articles that now appear anywhere in the United States. Provocative, original, and (not least) beautiin this journal set the standard for historical writing today." The Journal of Interdisciplinary History

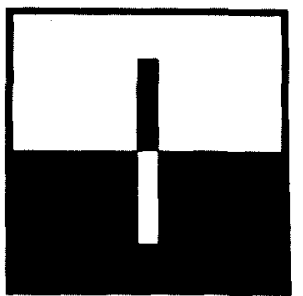

Rutgers University
"An immediate success, in a field that has had many failures and many mediocre enterprises, JIH has managed for the better part of two decades to remain a magazine of consistently high interest to a wide scholarly audience." - Jack P. Greene, The Johns Hopkins University

Unmatched by others in its field, The Journal of Interdisciplinary History is a highly distinguished publication that takes an exceptional approach to historical study. It incorporates the concepts and quantitative methods of the new history, bringing the best of economics, sociology, political science, archaeology, and demography into historical research.

Each issue of The Journal of Interdisciplinary History presents substantive articles and book reviews on topics spanning every geographical area and chronological period.

Go beyond the conventional approach to historical study. Subscribe to The Journal of Interdisciplinary History today!

Published quarterly by The MIT Press.

ISSN 0022-1953

\section{Yearly rates:}

Individual $-\$ 30.00$

Student and Retired $-\$ 25.00$

lnstitution $-\$ 70.00$

Outside U.S. and Canada, add $\$ 12.00$ surface mail or $\$ 18.00$ airmail postage.

Prepayment is required. Send check, drawn against a U.S. bank in U.S. funds, MasterCard or VISA number to:

\section{MIT Press Journals}

55 Hayward Street - Cambridge, MA 02142

(617) 253-2889 FAX: (617) 258-6779 


\section{Fertility Change on the American Frontier} Adaptation and Innovation

LEE L. BEAN, GERALDINE P. MINEAU, and DOUGLAS L. ANDERTON

The authors examine the marriage and chilbearing behavior of one predominatly Mormon population.

"Very important both for historical demography and for our evaluation of the theory about, and methodology relating to, fertility change, both in Western societies and in currently developing countries."

-Judith Blake, University of California, Los Angeles

\section{Religion and Society in a Cotswold Vale} Nailsworth, Gloucestershire, 1780-1865

\section{ALBION M. URDANK}

"This is a well-documented, readable, and thorough account of the ways in which religious conviction and its social environment interacted in an English village during the course of industrialization."

-Robert Wuthnow, author of Meaning and Moral Order

\section{America Becomes Urban}

\section{The Development of U.S. Cities and Towns, 1780-1980 ERIC H. MONKKONEN}

Now in paperback-"By restoring a sense of human agency to American urban history Monkkonen has gone a long way toward putting the politics back in to that history. At the same time his book carries an important message for the present: We cannot stop urban history but we can make-and unmake-it. Both of these accomplishments make this book an important one to read, assign, argue with, and learn from."-Joumal of Urban History \$12.95 paper

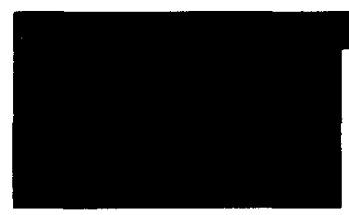

At bookstores or order toll-free 1-800-822-6657. Visa \& MasterCard only. University of California Press Berkeley 94720 


\section{The American Sociologist}

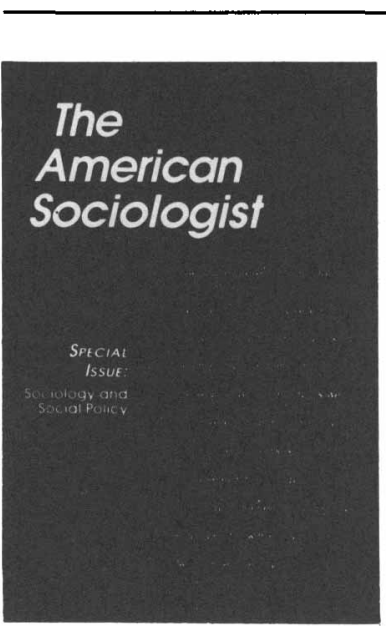

James L. McCartney, edltor

University of Missouri, Columbia

Examines the history, current status, and future prospects of sociology as a profession and discipline. The journal emphasizes the comings and goings of the profession, and focuses on how sociologists have shaped or try to shape social policy and the intellectual issues of the age. It also publishes professional opinions, special features, interviews, and review essays.

Rocent speclal foatures include:

Closing the Soclology Department at Washington University

David J. Pittman, Deidre Boden.

Robert $L$. Hamblin, Wolf Heydebrand, Patricia A. Adler, Peter Adler, Barbara S. Heyl, Henry Etzkowitz The Future of Sociological Theory Neil J. Smelser, James A. Beckford. Norbert Wiley, Stephen Tumer, David R. Maines Feminist Scholarship in Soclology Mary Jo Noitz, Paula England,

Susan A. Ostrander, Carol Brooks Gardner, Rose M. Brewer, Joey Sprague, Mary K. Zimmerman, Shulamit Reinharz, Xue Lan Rong, Linda Grant. Kathryn B. Ward Dual-Careerism and the Conjoint-Career Couple

Patricia A. Adler. Poter Adler,

Constance A. Ahrons, Morton S. Perlmutter, William G. Staples, Carol A.B. Warren

Publlahed Quartorly

Subscriptlon rates:

Individuals: $\$ 35 / y r ; \$ 60 / 2 y r s ; \$ 80 / 3 y r s$.

Institutions: \$60/yr; \$108/2yrs; \$145/3yrs.

Domestic first-elase mail add $\$ 15 / y r$.

Forelgn surface mall add \$15/yr.

Forelgn alrmall add \$30/yr. 


\section{Journal of World History}

Published by University of Hawaii Press in cooperation with the World History Association

Historical scholarship has traditionally dealt largely with the experiences of national communities. During the past quarter-century, however, historians increasingly have come to see the need to examine the effects of powerful historical forces that do not recognize national, or even cultural, boundaries - population movements, economic fluctuations, climatic changes, transfers of technology, the spread of infectious and contagious diseases, imperial expansion, long-distance trade, and the spread of religions and ideals. As a result, a substantial body of literature examining these forces has emerged.

The Journal of World History is the first journal devoted specifically to world history as a field of research and teaching. The journal publishes articles on such global themes as:

- comparative studies of developments that affect more than one civilization or cultural region

- studies in the historiography of world history

- analyses of encounters between peoples of different civilizations or cultural regions

- reflections on conceptualization and periodization in world history

The Journal of World History will appear twice a year beginning in January 1990. Individual subscriptions are regularly US $\$ 25 / y \mathrm{r}$ and include membership in the World History Association. Send address information and checks, payable to the World History Association, to Professor Richard Rosen, World History Association, Department of History and Politics, Drexel University, Philadelphia, PA 19104 USA, phone (215) 895-2471. Submit manuscripts to Professor Jerry H. Bentley, Department of History, University of Hawaii, Honolulu, HI 96822 USA. 


\section{JOURNAL OF \\ American Ethnic History}

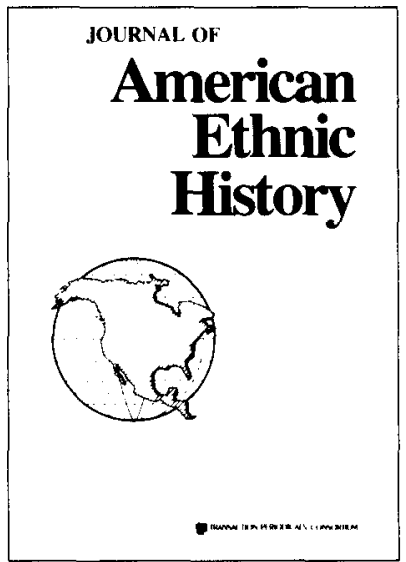

JOURNAL OF

American Ethnic History

Recent articles include:

The War on Intolerance: The

Reformulation of American Nationalism, 1939-1941

Richard W. Steele

"America Is the Woman's Promised Land": Swedish Immigrant Women and

American Domestic Service

Joy K. Lintelman

Reconsidering the Rosenbergs: Symbol and Substance in Second Generation American Jewlsh Consciousness Deborah Dash Moore

Culture and Education in the American Southwest: Towards an Explanation of Chicano School Attendance, 1850-1940 Guadalupe San Miguel, Jr.

Published Semiannually

The official journal

of the Immigration History Soclety.

Subscription rates: **

Individuals: $\$ 17 / y r ; \$ 34 / 2 y r s ; \$ 47 / 3 y r s$.

Institutions: $\$ 32 / y r ; \$ 64 / 2 y r s ; \$ 91 / 3 y r s$.

Domestic first-class mail add $\$ 15 / \mathrm{yr}$.

Foreign surface mail add $\$ 15 / y$ r.

Forelgn airmail add $\$ 25 / \mathrm{yr}$.

** Includes membership in the Immigration History Society and semiannual Immigration History Newsletter. 
EDITOR

Eric Monkkonen, University of California, Los Angeles

ASSOCIATE EDITOR

Robert P. Swierenga, Kent State University

BOARD OF EDITORS

Barbara Anderson, University of Michigan

William O. Aydelotte, University of Iowa

Lee Benson, University of Pennsylvania

Allan G. Bogue, University of Wisconsin

William Clagett, Florida State University

Ellen Dwyer, Indiana University

Heinz Eulau, Stanford University

Roderick Floud, University of London

David W. Galenson, University of Chicago

Alice Goldstein, Brown University

Myron P. Gutmann, University of Texas at Austin

David I. Kertzer, Bowdoin College

J. Morgan Kousser, California Institute of Technology

Robert C. Liebman, Portland State University

Terrence McDonald, University of Michigan

Patrick Manning, Northeastern University

Warren Miller, Arizona State University

Leslie Moch, University of Michigan, Flint

Karen Orren, University of California, Los Angeles

John Padgett, University of Chicago

Donald Parkerson, East Carolina University

Richard Steckel, Ohio State University

John J. TePaske, Duke University

Susan Cott Watkins, University of Pennsylvania

Ian Winchester, Ontario Institute for Studies in Education

SSHA EXECUTIVE DIRECTOR

Howard W. Allen, Southern Illinois University

EDITORIAL ASSISTANT

Matthew C. Lee 


\section{Cambridge University Press}

\section{Working-Class Americanism}

The Politics of Labor in a Textile City, 1914-1960

Gary Gerstle

"...a major contribution to our understanding of the class and ethnic dynamics of New Deal America and of the continuities linking that epoch of social reform to the urban experience that preceded and followed it."-David Montgomery, Farnam Professor of History, Yale University Interdisciplinary Perspectives on Modern History

36131-1 Hardcover $\$ 39.50$

\section{The Emergence of the Middle Class}

Social Experience in the American City, 1760-1900

\section{Stuart M. Blumin}

" $\ldots$ the most important effort to date to bring the question of middle-class formation into the critical caldron of social change in early 19th-century America in the seaboard cities. The best of his evidence is from Philadelphia, whose social history he has mined with diligence and ingenuity. (There are appropriate comparisons with New York and Boston.)"

-Daniel T. Rodgers, The New Republic

Interdisciplinary Perspectives on Modem History

25075-7 Hardcover \$49.50 37612-2 Paper \$14.95

Now in paperback...

\section{Ethnic Differences}

Schooling and Social Structure Among the Irish, Italians, Jews, and Blacks in an American City, 1880-1935

\section{Foel Perlmann}

“... a most remarkable book. Perlmann's analysis of ethnic differences in education is amazingly rich. He brings much new evidence to bear on debates about the importance of culture and class in America, and he treats the issues with great intelligence. This book will be essential for anyone concerned with the interplay of race, class, and culture in American society, and in the schools." - David Cohen, Michigan State University

Interdisciplinary Perspectives on Modern History

35093-X Hardcover \$42.50 38975-5 Paper \$14.95

\section{The Heart of the Commonwealth}

\section{Society and Political Culture in Worcester County, Massachusetts, 1713-1861}

\section{Fohn L. Brooke}

This book interprets the impact of national and industrial revolution on the social and cultural fabric of one Massachusetts county. Exploring the role of republican and liberal ideologies in recurring cycles of political consensus and insurgency over the century and a half before the Civil War, it presents a model for understanding the social construction of public culture in early America.

37029-9 Hardcover \$34.50

\section{Worlds Within Worlds}

\section{Structures of Life in Sixteenth-Century London}

\section{Steve Rappaport}

The enormous growth of London during the early modern period brought with it major social problems. Yet, as Professor Rappaport demonstrates through analysis of the individual careers of over one thousand inhabitants, the institutional superstructure of the city was more adaptable, its small social organizations more resilient, and opportunities for social mobility far greater than many historians have recognized.

Cambridge Studies in Population, Economy and Society in Past Time 7

35065-4 Hardcover $\$ 54.50$

At bookstores or from

\section{CAMBRIDGE UNIVERSITY PRESS}

40 West 20th Street, New York, NY 10011. Call toll-free $800-872-7423$ outside NY State. 800-227-0247, NY State only. MasterCard/NISA accepted. Prices subject to change. 